\title{
The Development of Emergent Literacy in Serbian Kindergartens: Basic Resources and Related Practices $^{1}$
}

\author{
Nada Ševa ${ }^{2}$ \\ Institute for Educational Research, Belgrade \\ Jelena Radišić \\ Institute for Educational Research, Belgrade
}

\begin{abstract}
This study explores the basic resources available in kindergartens and practices of kindergarten teachers that literature recognizes as supportive for the development of emergent literacy in 3-5 year-old children. 374 kindergarten teachers from 10 different districts at the territory of the city of Belgrade filled in a questionnaire on the frequency of storybook reading, the number and types of books available to children and their use of electronic media (e.g. television programmes, cartoons) in their everyday practices with children. The results indicate that current educational programmes in Serbia do not explicitly support the development of emergent literacy in 3-5 year-old children. Although teacher initiated reading is embedded in daily kindergarten activities, our kindergartens hardly fulfil the necessary conditions with respect to print rich environment (1-3 books on the average, compared to the minimum of 5). TV sets are present in $85 \%$ of kindergartens, with $45 \%$ directly available to children in their rooms. Although children mainly watch TV 1-3 times per week, it is used mostly for entertainment, with only $34 \%$ of teachers using it as an educational tool in the interaction with children. Future directions of research on practices and beliefs related to emergent literacy, both in kindergartens and at home, are discussed.
\end{abstract}

Keywords: emergent literacy, kindergarten teachers' practices, kindergarten resources

\section{Introduction}

During the last decade a substantial number of countries have placed more emphasis on the development of emergent literacy in their kindergartens through changes of current policies and practices. This was motivated by several factors, including the developments in the theory of literacy in general (Gee, 1999; Mitrović, 2010a; Street, 2003), the developments in research on emergent literacy (for a detailed review see Sénéchal, LeFevre, Smith-Chant, \& Colton, 2001; Whitehurst \& Lonigan,

1 This paper was supported by the Ministry of Education, Science and Technological Development of the Republic of Serbia, grant numbers 179034 and 47008.

2

nadaseva@gmail.com 
1998), and finally, the results of several national and international surveys on the development of literacy in primary school children (Lee, Grigg \& Donahue, 2007; Mullis et al., 2012), partially related to language and literacy competencies developed in preschool years.

In this study we will present a survey of basic printed and electronic resources available in kindergartens as well as related practices of kindergarten teachers that help emergent literacy development in Serbian 3-5 year-old children. Additionally, in order to enhance understanding of the overall context of this phenomenon, we will first provide an overview of the current theoretical framework regarding emergent literacy, together with the short summary of the existing state approved kindergarten curricula related to the development of emergent literacy in North America (US and Canada), the Commonwealth countries (Australia and New Zealand) and European countries.

\section{Definition of emergent literacy}

Current educational and developmental literature defines emergent literacy as a composite concept that includes knowledge and skills related to the development of oral language, meta-linguistic awareness and written language in children, aged 0 to 5 . This term was created in the mid-60s of the $20^{\text {th }}$ century, although a more formal definition came with the Teale and Sulzby's book, Emergent Literacy: Writing and Reading (Teale \& Sulzby, 1986). The concept of emergent literacy is based on the assumption that the process of literacy starts in early childhood, long before formal education, through early contact with print (for example, through children's books, Lego toys, computers, etc.) and that it serves as a basis for a lifelong learning process.

This idea is directly connected to the New Literacy Studies, where literacy was no longer defined as a monolithic and autonomous activity, isolated from the social context and acquired through formal educational system as a cognitive skill solely (for a more detailed review see Gee, 1999; Mitrović, 2010a; Street, 2003). It is rather perceived as a combination of different socio-culturally and contextually determined types of literacy, which develops through the entire life span and should be nourished from earliest childhood. Thus, when we converse about literacy, we do not necessarily imply a simple encoding of oral language into written code (and vice versa), but any set of social practices mediated by written texts (including mobile texting, blogging, cartoons like Dora the Explorer or even graffiti writing) (Snow, 2004).

Based on the overview of previous research on the development of emergent literacy concept, Whitehurst \& Lonigan (1998) proposed two related dimensions that constitute emergent literacy: inside-out and outside-in processes. Inside-out components would include skills such as the knowledge of the rules of decoding a particular phoneme into a grapheme (or vice versa), the detection of rhyme (phonological awareness), the repair of grammatical errors (syntactic awareness) and invented spelling. Outside-in dimension includes the skills necessary for understanding of what is read (semantic, syntactic and conceptual knowledge), understanding and producing narrative, the knowledge of standard print format (e.g. left-to-right, frontto-back orientation), as well as pretending to read.

In addition, Sulzby and Teale (1996) emphasized the role of family and community as an integral element in the development of emergent literacy, with storybook reading as the most prevalent form of literacy interactions not only in the home environment, but also in the kindergarten context. 


\section{Reading readiness vs. Emergent literacy}

Emergent literacy is the concept directly contrasted to the reading readiness philosophy. Throughout the first fifty years of the $20^{\text {th }}$ century, reading readiness was the term used to denote neural maturation - 'ripening' necessary to begin with the process of reading and, subsequently, writing (Manson \& Sinha, 1992). According to this view, children were unable to grasp the basic concepts of decoding sounds into letters (and vice versa) before the age of seven and one should not start with reading instructions until the cognitive system develops fully, since it would have a counter effect on child's reading performance.

During the 1950s and 1960s, the definition of reading readiness was changed towards a more active approach in a preschool setting regarding the development of the skills necessary for reading and writing. In addition to the 'waiting' philosophy towards the starting point of direct reading and writing instructions, the preschool period should be filled with rigorous instructions and drills for the development of necessary skills related to reading and writing, like phonological awareness, letter names and sounds (phonics instructions), visual discrimination and memory. These contradictory assumptions ('waiting' philosophy vs. instruction and drill practice), combined within the reading readiness concept, were seen as a focal point for its critique (Coltheart, 1979, as cited in Mason \& Sinha, 1992). However, the reading readiness theory continued to be a dominant paradigm of thinking at the level of curricula, teachers' practices and beliefs until the end of the $20^{\text {th }}$ century.

The change towards a more emergent literacy approach was initiated both due to theoretical movements in the field of literacy (discussed above), and to the results of several national or international surveys on the development of literacy in school children, partially related to language and literacy competencies developed in preschool years. Namely, the latest surveys on literacy development in primary grades have shown that one third of the $4^{\text {th }}$ grade students in the United States cannot read at their grade level (Lee, Grigg \& Donahue, 2007). This was related both to poor teaching instructions and professional development practices, especially in early primary grades, but also to poor emergent literacy competencies (Gersten, et al., 2008; Josh, 2010). Additionally, several longitudinal studies implied that rich vocabulary and rich print exposure, together with emergent reading skills acquired during the kindergarten age, strongly correlate and determine the results on literacy competencies measures up to the $11^{\text {th }}$ grade (16-17 years) (Cunningham \& Stanovich, 1997; Duncan et al., 2007; Hart \& Reisly, 2003).

Thus, it is not surprising that a relatively large number of countries took the abovementioned data into serious consideration and placed emphasis on the development of emergent literacy in their kindergarten curriculum, deemed necessary for subsequent successful reading and writing in the school context. In the next section of this paper we will provide a short overview of the current curricular changes in North America (the USA and Canada), the Commonwealth countries (Australia and New Zealand) and European countries.

Although the emergent literacy concept was present in the curricula like High Scope, Pre-k or Illinois Curriculum, in the USA it became a part of the nationwide curricula through the No Child Left Behind Act (2001), introduced by the U.S. Department of Education. One of the main programmes within this project is the 
Early Reading programme, with the main goal to "... prevent reading failure by providing a high-quality early education to young children, especially children from low-income families" (U.S. Department of Education, 2002, p. 27).

Parallel to this, the latest surveys on changes of preschool curricula, including the policies on emergent literacy development (Ispa, 2002; OECD, 2006; ELECT, 2007; Tafa, 2008; Skiver, 2011) had shown that the reading readiness philosophy had been deeply entrenched in curricular practices until recently and that it became replaced in the past decade with emergent literacy views on reading and writing development in a relatively large number of countries such as the UK, Belgium, France, Finland, Greece, Ireland, Portugal, Spain, Denmark, Sweden, Russia, Canada (Ontario), Australia, New Zealand, Netherlands, Korea, Mexico, Germany, Austria, Hungary, the Czech Republic.

The curricula do differ on the continuum between: a) pre-primary curricula found in the countries like the US, UK or France where the focus is on learning standards useful in reaching the school readiness level (e.g. oral competence, phonological awareness, letter/word recognition) vs. b) social pedagogy tradition curricula found in the Nordic countries or Italy, where the focus is on broad developmental goals achieved through play rather than prescribed outcomes, with the family completely included in the educational process (e.g. symbolic representation, family literacy, exploration of written language) (OECD, 2006; Tafa, 2008). In addition, some researchers emphasize that the observed differences between curricula across countries might emerge due to the orthographic shallowness present in languages like Finish or Russian, where reading development rate is more than twice as fast as for the deep and complex orthographies like in English. Subsequently, the Finish or Russian children are not expected to learn to cite the alphabet (Josh, 2010; Snow, 1994; Seymour, Aro, \& Erskine, 2003).

However, a common ground in all curricula is established at the level of encouragement of the activities which help children to do the following:

1. to develop their oral language skills, like vocabulary and listening comprehension (more about the importance of constant verbal interactions with adults - family and teachers, and peers for the development of early vocabulary, in Hart \& Reisly, 2003);

2. to be actively engaged in literacy activities with teachers (as mediators) and peers;

3. to understand the communicative nature of reading and writing.

In addition, the professional development of teachers was emphasized as one of the pillars for the successful emergent literacy development, underlining that the programmes for teachers' education should be based on current scientifically based reading research on how children learn to read and write and the best instructional practices to help them learn (IRA/NAEYC, 1998; Strickland \& Riley-Ayers, 2006).

When it comes to the resources necessary for the development of emergent literacy, recommendations are that learning to read and write should be done in a printenriched classroom environment, which includes both richer and more genre diverse selection of books, readily presented and available to children in the room, as well as the presence of logos, posters, signs or labels (Tafa, 2008). This recommendation was based on a big intervention programme called Book Aloud (Neuman, 1999; Neuman \& Celano, 2001). The programme initially included screening the state of the physical 
environment of the rooms in 100 kindergartens (e.g. the number of books, the state of furniture for the book centres if present, the number of other print materials (e.g. logos, posters, etc.), the presence of TV sets etc.). The results of the survey led to enriching the child-care rooms with a minimum of 5 books per child and different genre titles (e.g. classic or folk fairytales, poetry, encyclopaedias, cartoon-based titles, content or graphically modern titles) that allowed children to explore books in a manner that is more aligned with the emergent literacy concept (Mitrović, 2010b). In addition, in the majority of kindergartens, teachers had to reorganize the rooms in order to display books in a more accessible, cosy environment, which included low-levelled open bookshelves, rugs or beanbag chairs for children to sit on in the book corner, etc. Parallel to this, kindergarten teachers went through an extensive training programme intended to raise their awareness of the importance of emergent literacy, help them develop better strategies for reading aloud to children, as well as the techniques to enhance children's responses to stories. Teachers were then supervised every two weeks for seven months in their facility. The outcome of the intervention led to more child-teacher literacy related interactions per hour (e.g. doing a world puzzle, spelling, or a writing/drawing activity) and increased the number of times that teachers read to children, as well as the overall number of minutes devoted to reading during the day. Finally, compared to the control group, the children from the Books Aloud group asked more frequently to be read to as well as the questions about reading. In addition, the children from the Books Aloud group did better on the individual assessments of emergent literacy development like: concepts of print, letter name knowledge, the concepts of narrative and the concepts of writing. More importantly, these effects pertained six months after the intervention programme had been completed.

There are also some recommendations with respect to learning to read and write through electronic media. In the US, there is a live and controversial debate on the use of electronic media (TV, computer games) in the emergent literacy development. On the one hand, very strong opinions are expressed towards the strict prohibition of TV and computers for children under the age of 2, and a very limited use for preschoolers in order to increase creative play time (Vandewater, Bickham, \& Lee, 2006; American Academy of Paediatrics Council on Communications and Media, 2011). Contrary to this, a growing number of studies imply that some TV programmes like Dora the Explorer, Arthur or Sesame Street have a positive effect on the emergent literacy development, when watched with an adult in interactive way (Anderson, et al, 2001; Linebarger \& Walker, 2005; Penuel, et al., 2009). These findings do propose and encourage more media-rich emergent literacy curricula.

The short overview of international curricular and practice related changes has shown that the implementation of emergent literacy views is still not unified and is deeply culturally, socially and linguistically determined. Thus, it is always informative and interesting to extend the corpora of data with the examples from different counties. In the next section we will describe the present situation in the development of emergent literacy for Serbian, a South Slavic language with shallow orthography.

\section{Serbian kindergartens and emergent literacy}

Although numerous studies addressed the question of literacy in the educational context of Serbia from the theoretical (for a more detailed review see Mitrović, 2010a) and empirical perspective (e.g. Baucal, 2010; Baucal et al., 2006; Dragićević, 2007; 2012; Krnjaić, Stepanović, Pavlović-Babić, 2011; Pavlović-Babić, Baucal, 2009; 
Pavlović-Babić, 1998; Šefer, Lazarević \& Stevanović, 2008), only two recent papers recognized the importance of emergent literacy for subsequent formal education of reading and writing, setting some standards on the important parameters for the development of emergent literacy (Anđelković, 2012; Mitrović, 2010b).

At the level of legislation, it appears that Serbia is closer to the countries like Luxembourg (Tafa, 2008), where the reading readiness philosophy is still actively present in official state educational programmes. Preschool education in Serbia is defined through several legal documents including: the Law on Preschool Education (The Official Gazette of the Republic of Serbia No. 18/2010), the Book of regulations of fundamentals for preschool programmes (The Official Gazette of the Republic of Serbia No. 14/2006) and the Book of regulations on educational resources necessary for work of preschool institutions (The Official Gazette of the Republic of Serbia No. 46/1994). Preschool education system in Serbia operates with two equally used models: Model A, which is more in line with the social pedagogy tradition curricula, similar to the ones found in the Nordic countries, and Model B, which puts more emphasis on predefinition of educational goals and activities as well as the role of kindergarten teachers (the Book of regulations of fundamentals for preschool programmes, p. 24).

When it comes to emergent literacy development, neither of these models nor any of legislative documents recognizes emergent literacy as a parameter of development relevant for kindergarten children at the age $3-5^{3}$. For example, the Book of regulations of fundamentals for preschool programmes sets the framework of emergent literacy development only for children at the age of 6 , when the compulsory preparation period for primary school starts (Model A: pp. 121-124, Model B: pp. 156-158). As for the 3-5 age groups (Book of regulations of fundamentals for preschool programmes, pp. 24-111), we have searched for keywords like literacy (in Serbian "pismenost"), reading (in Serbian "čitanje"), writing (in Serbian "pisanje"), learning to read and write (in Serbian "opismenjavanje"), and storybook reading (in Serbian "čitanje priča/knjiga"). The keywords literacy and learning to read and write had a frequency 0 . Reading and writing appeared only at page 27 (the section of Model A), in the following statement: "Taking into consideration developmental and graphic-motor abilities of preschool children, kindergartens are not directly responsible for teaching children reading, calculating and writing. That, of course, does not mean that some children and kindergartens will not express the need to learn letters at preschool level." 4 In addition, writing was mentioned in the context of writing boards used in the Centre for the development of oral language (the description of Model A, p. 63). Storybook reading was only mentioned once (p. 75), as an example of activities which have to take place in front of the whole group, rather than individually or in small groups.

Furthermore, the Book of regulations on educational resources necessary for work of preschool institutions registers the literacy resources (mainly books of different

3 All documents (e.g. the Book of regulations of fundamentals for preschool programmes) were analysed as a whole. It was examined how the concept of literacy was utilized, as well as which features were recognized as those contributing to the emergent literacy development. Finally, for the features recognized in documents, we looked at how the criteria for their fulfilment were defined.

4 Translated by the authors. 
genres, like fairy tales, poetry, etc.) as necessary for work with children, but does not specify the minimum number of books. Interestingly, the document defines the specific number of all other resources (e.g. 5 boxes of chalks, number of dolls i.e. baby dolls 8 , animal toys 5 , etc.)

As it comes to professional development, the Institute for Improvement of Education ${ }^{5}$ provides over 80 educational programmes for education of preschool teachers. Only 13 are related to the development of oral language or enhancing reading readiness for 6 year-olds and there is no programme on the development of emergent literacy for children younger than 5 .

Given that the educational programmes in Serbia do not explicitly support the concept of emergent literacy for the age 3-5, we wished to explore how the concept is recognized in practice, among kindergarten educators. In particular, we focused on two questions: a) given that the number of books and use of TV in kindergartens are not specifically defined in our legislative we were interested in what their current distribution is and $b$ ) how kindergarten teachers organize their daily activities related to emergent literacy with books and TV as their main tools. In spite of the fact that this is an exploratory study, we find it to be of particular importance for the current Serbian educational context, since recent results of national testing of $3^{\text {rd }}$ grade primary students showed that $30 \%$ of students were at or below the basic level of literacy achievements (Baucal, Pavlović-Babić, Gvozden \& Plut, 2006). Since similar effects observed in the US children have been at least partially related to the emergent literacy development in kindergarten (Lee, Grigg \& Donahue, 2007), it would be interesting to open for the first time the question of emergent literacy development in the Serbian context in a more systematic way.

\section{Methodology}

Sample. Study participants were kindergarten teachers from ten districts (out of 17, both centre- and suburb-based) in the city of Belgrade. All kindergarten teachers were contacted through the Association of kindergarten teachers of the city of Belgrade, and 374 of them, coming from 67 different kindergarten facilities, agreed to participate in the survey by filling in a questionnaire. Only kindergarten teachers working with age groups 3-5 participated in the study. All participants were women working in public kindergartens. Although, on the average, study participants were equally distributed in terms of their age (age groups 25-29, 30-39, 40-49 and 50-54 years of age), a lower percentage of kindergarten teachers can be found in the "below 25 " and "above 55 " age groups (together approximately less than 10\%). Considering the educational attainment of study participants, most kindergarten teachers completed college (an average for 10 municipalities $82 \%$ ).

Variables. The focus of this paper was on the availability of books in kindergartens and practices related to reading, as well as the use of media in kindergartens. The former aspect was operationalized through: (1) availability of books in the facility (a

5 Current catalogue of professional development programmes was retrieved on March $14^{\text {th }}, 2013$ from the World Wide Web http://www.zuov.gov.rs/novisajt2012/dokumenta/CPRZO/katalog2012-2014.pdf 
categorical variable, includes categories in the play room, facility library and other), (2) the number of available books (an ordinal variable including six categories: none, 1-20 books, 21-40, 41-60, 61-80 and over 81 books; the information was asked for the facility library and the play room), (3) the time of day when reading activity occurs (a categorical variable, includes morning activities, before bedtime, before parents' arrival and other), (4) types of books available (a categorical variable, five categories of predefined types of reading materials), (5) the most frequent types of titles (an openended question, in the analysis the variable was categorized), (6) the frequency of reading initiated by the kindergarten teacher within a week period, (7) the frequency of children asking to be read to and (8) the frequency of pretend to read activities. Variables 6, 7 and 8 are Likert-type scale variable, five categories: never, 1-3 times per week, 4-5 times per week, every day up to one hour, every day over one hour.

The use of electronic media in kindergartens was operationalized through (1) the availability of $T V$ sets in the facility and/or room (a categorical variable, information gathered for the play room and the whole facility, categories yes/no), (2) the frequency of children watching cartoons on DVDs and cable TV within a week period, (3) the frequency of watching feature-length movies, children's entertainment and educational programmes and (4) the frequency of using television in joint activities with children in order to better illustrate the topic of the activity. Variables 2, 3 and 4 are Likert-type scale variable, five categories: never, 1-3 times per week, 4-5 times per week, every week day up to one hour, every day over one hour.

Instrument. The questionnaire comprised two separate areas: (a) the first focusing on the availability of books in kindergartens and practices related to reading; and (b) the second focusing on practices related to the use of electronic media in kindergartens. The dominant form of questions in the instrument was Likert-type (for details please refer to the variable section).

Procedures. The first level of analysis was descriptive. The $\chi^{2}$ test was used to assess whether the paired observations of variables were independent of each other, while Pearson product-moment correlation coefficient and Spearman's rank correlation coefficient were utilized to measure dependence between the variables. All analyses were conducted using the SPSS 20 software package.

\section{Results}

Nearly all kindergarten teachers participating in the study stated that books were present in the rooms where they spent time with children (99.5\%), while almost half of them $(46.4 \%)$ stated that areas with books (e.g. the library, reading corners) were also present in the premises of the building where they work. However, the number of books available in the rooms varies. Only 15\% of kindergarten educators reported this number to be above 60 books per room (Figure 1).

The results indicate a significant association between the number of books available per room and the location of the kindergartens. More specifically, a considerable number of kindergartens in central districts have more than 81 books in their rooms, whereas a higher proportion of kindergartens in the suburban area have less than 20 books in their rooms $(\chi 2=15.25$, Cramer's $V=.205, \mathrm{df}=5, \mathrm{p}<0.05)$. 
Figure 1. Number of books available in rooms

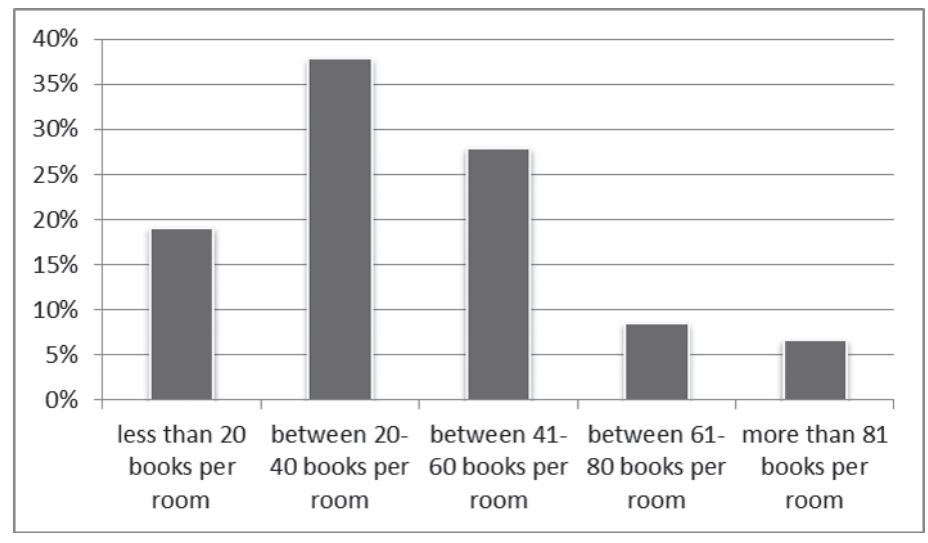

As mentioned above, we also asked kindergarten teachers whether a separate library or a reading corner existed in the kindergarten. In 36 kindergartens (54\% of the sample), teachers did not agree among themselves whether a separate library or a reading corner actually existed or not. The same pattern of inconsistency was again noticeable concerning the number of books available in libraries (if they existed). Different kindergarten educators from the same kindergarten reported on a different number of books available in the library (or the reading corner). This was noticeable in 38 kindergartens out of 67 (57\% of the sample).

During children's stay in the kindergarten morning is the time when reading activities dominate $(69.5 \%)$ as part of daily structured activities, followed by reading before afternoon nap time $(61.2 \%)$. Almost $38 \%$ of kindergarten teachers informed that they read to children also just before their parents come to pick them up. Two thirds of kindergarten teachers marked at least two time slots (e.g. morning activities and before nap time, the period while waiting for parents and before nap time, etc.) in their responses as the most frequent periods when they read to children.

We inspected for the type of titles available in kindergartens and thus read to children. Although picture books with traditional fairy tales and fables, picture books based on modern cartoon characters, new children's titles, encyclopaedias and children's poetry are all available among different titles (Table 1), when teachers were asked what was the most frequent type of titles in their opinion, $80 \%$ listed picture books with traditional fairy tales and fables as the most dominant in kindergartens.

Table 1. Types of titles available for reading in rooms

\begin{tabular}{|l|c|}
\hline \multicolumn{1}{|c|}{ Types of titles available for reading in rooms } & $\begin{array}{c}\text { \% of kindergarten teachers } \\
\text { reporting that a particular type } \\
\text { of books exists in rooms }\end{array}$ \\
\hline $\begin{array}{l}\text { - Picture books with traditional fairy tales and fables (e.g. } \\
\text { Cinderella, Three little pigs) }\end{array}$ & $98.4 \%$ \\
\hline $\begin{array}{l}\text { - Picture books based on modern cartoon characters (e.g. } \\
\text { Peppa the Pig, Little Princess) }\end{array}$ & $50.0 \%$ \\
\hline - New children's titles (e.g. Scaredy squirrel by Melanie Watt) & $51.8 \%$ \\
\hline - Encyclopaedias or other educational materials & $79.7 \%$ \\
\hline - Children's poetry (e.g. Jovan Jovanović Zmaj, Duško Radović) & $77.0 \%$ \\
\hline
\end{tabular}


As for the frequency of story book reading at the weekly level (Figure 2 shows summarized descriptives), $82.1 \%$ of kindergarten teachers participating in the study reported on reading to the children in their group (almost) every day. A rather high number of kindergarten educators (17\%) reported on such practice 1-3 times a week. At the same time, $71.1 \%$ of kindergarten teachers reported that the children aged 3-5 asked to be read to on an almost daily basis. If we look at the activity related to "pretending to read", $74 \%$ of kindergarten teachers reported that children took books "to read" almost every day. All three constructs (the frequency of reading to the child, the child asking to be read to, the pretend reading) are mutually positively correlated at 0.001 level (Pearson's $\mathrm{r}$ ranging from 0.32 to 0.63 ). Small but significant positive correlations were also found between the number of books available in rooms and the child asking to be read to, and the number of books available in rooms and children's pretend reading activities (Spearman's r ranging from 0.13 to 0.17 ). See Table 3 for details.

Figure 2. Frequency of storybook reading at the weekly level

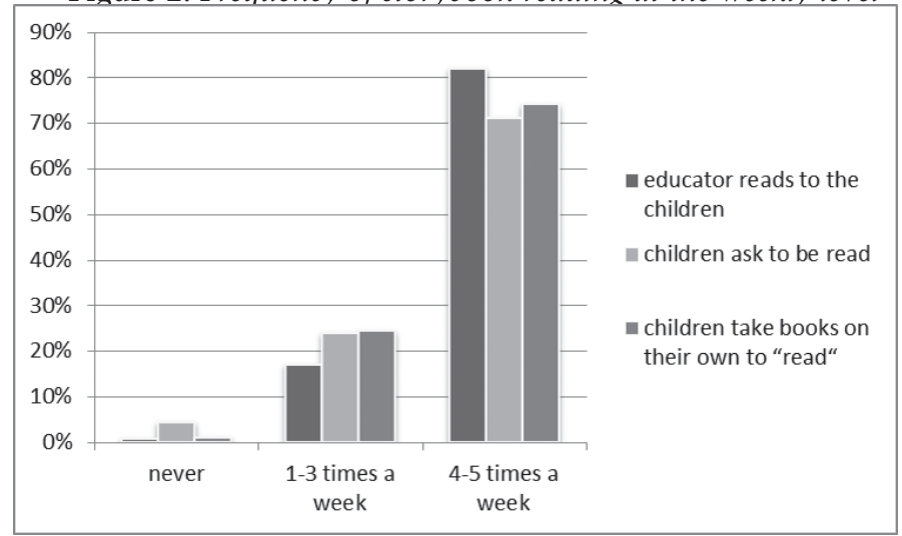

The use of electronic media was also explored among kindergarten teachers as part of their everyday routine with children. Among study participants, $85 \%$ said that a television set existed in their kindergarten (a separate room with a TV), whereas $45 \%$ said the TV set existed in their rooms as well. Yet, municipalities differ in that policy - while in some municipalities watching TV is part of daily routines, in some areas of Belgrade TV is still banned from kindergartens (Table 2). We have not found statistically significant correlations between the existence of TV sets in rooms and the amount of practices related to the frequency of child asking to be read to or pretend reading activities. However, a statistically significant negative correlation was established between the presence of television sets in children's rooms and the frequency of weekly reading initiated by the kindergarten teacher (Spearman's $\mathrm{r}=-0.43, \mathrm{p}<0.05$ ).

Table 2. Frequency of using electronic sources per type of content (week)

\begin{tabular}{lrrr}
\multicolumn{1}{c}{ Type of Activity } & Never & $\begin{array}{c}1-3 \text { times } \\
\text { a week }\end{array}$ & $\begin{array}{c}4-5 \text { times } \\
\text { a week }\end{array}$ \\
\hline How often do children watch cartoons on DVD? & $39.9 \%$ & $51.7 \%$ & $8.4 \%$ \\
How often do children watch cartoons on cable TV? & $90.1 \%$ & $8.5 \%$ & $1.4 \%$ \\
How often do children watch feature-length movies (e.g. Ice age, Shrek)? & $61.6 \%$ & $35.9 \%$ & $2.5 \%$ \\
$\begin{array}{l}\text { How often do children watch children's entertainment and educa- } \\
\text { tional programmes (e.g. Kefalica, Kockica)? }\end{array}$ & $76.9 \%$ & $20.6 \%$ & $2.6 \%$ \\
$\begin{array}{l}\text { How often do you use the contents of television and the Internet in joint } \\
\text { activities with children in order to better illustrate the topic of the activity? }\end{array}$ & $66.3 \%$ & $27.1 \%$ & $6.6 \%$ \\
\hline
\end{tabular}


If we observe the frequency of using different electronic resources during one week period, they are most often used in an interval of 1-3 times per week (we account here the five working days during which children attend kindergartens). The cartoons on cable TV are still somewhat "banned" from kindergartens (Table 2 ), with kindergarten teachers rather opting for children watching feature-length movies (e.g. Ice age, Shrek) 1-3 times a week (36\%) or cartoons on DVDs (52\%). One fifth of kindergarten teachers said children watched entertainment and educational programmes appropriate to their age (e.g. Kefalica, Kockica) 1-3 times a week, while $27 \%$ of educators used the contents of television and the Internet in joint activities with children in order to better illustrate the topic of the activity.

Small but statistically significant positive correlations were established between the frequencies of weekly reading initiated by the kindergarten teacher, the child asking to be read to or pretend reading activities on the one hand and the frequency of children watching age-appropriate entertainment and educational programmes and teachers' use of contents of television and the Internet in joint activities with children to better illustrate the topic of the activity (Pearson's $r$ ranging from 0.11 to 0.15 ; Table 3 ).

Table 3. The relationship between activities

which include use of different electronic sources per type of content (week)

\begin{tabular}{|c|c|c|c|c|c|c|c|c|c|c|c|}
\hline \multicolumn{2}{|c|}{$\begin{array}{l}\text { Activity frequency at the } \\
\text { weekly level }\end{array}$} & 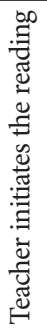 & 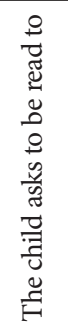 & 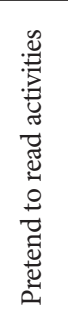 & 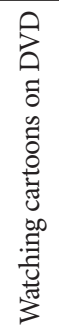 & 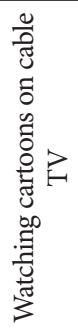 & 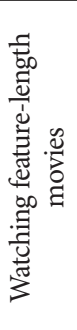 & 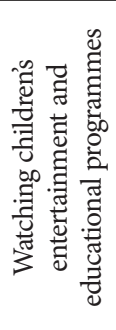 & 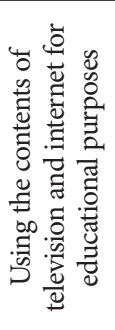 & & 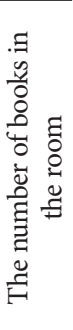 \\
\hline \multirow{2}{*}{ Teacher initiates reading } & $\mathrm{r}$ & 1 & $.63^{* *}$ & $.32^{* *}$ & .05 & .04 & .07 & $.12^{*}$ & $.15^{* *}$ & $r_{s}$ & .09 \\
\hline & sig. & & .000 & .000 & .39 & .45 & .20 & .02 & .01 & sig. & .06 \\
\hline \multirow{2}{*}{$\begin{array}{l}\text { The child asks to be } \\
\text { read to }\end{array}$} & $\mathrm{r}$ & & 1 & $.41^{* *}$ & .05 & .06 & .09 & $.14^{* *}$ & $.12^{*}$ & $\mathrm{r}_{\mathrm{s}}$ & $.13^{* *}$ \\
\hline & sig. & & & .000 & .30 & .29 & .09 & .01 & .02 & sig. & .01 \\
\hline \multirow{2}{*}{$\begin{array}{l}\text { Pretend to read } \\
\text { activities }\end{array}$} & $\mathrm{r}$ & & & 1 & -.05 & .06 & -.05 & $.12^{*}$ & $.11^{*}$ & $\mathrm{r}_{\mathrm{s}}$ & $.17^{* *}$ \\
\hline & sig. & & & & .36 & .27 & .36 & .02 & .04 & sig. & .00 \\
\hline \multirow{2}{*}{$\begin{array}{l}\text { Watching cartoons on } \\
\text { DVD }\end{array}$} & $\mathrm{r}$ & & & & 1 & $.14^{*}$ & $.49^{* *}$ & $.19^{* *}$ & .07 & $\mathrm{r}_{\mathrm{s}}$ & $-.13^{*}$ \\
\hline & sig. & & & & & .01 & .000 & .000 & .18 & sig. & .02 \\
\hline \multirow{2}{*}{$\begin{array}{l}\text { Watching cartoons on } \\
\text { cable TV }\end{array}$} & $\mathrm{r}$ & & & & & 1 & $.22^{* *}$ & $.31^{* *}$ & $.30^{* *}$ & $\mathrm{r}_{\mathrm{s}}$ & $.15^{* *}$ \\
\hline & sig. & & & & & & .000 & .000 & .000 & sig. & .00 \\
\hline \multirow{2}{*}{$\begin{array}{l}\text { Watching feature-len- } \\
\text { gth movies }\end{array}$} & $\mathrm{r}$ & & & & & & 1 & $.37^{* *}$ & $.15^{* *}$ & $\mathrm{r}_{\mathrm{s}}$ & -.04 \\
\hline & sig. & & & & & & & .000 & .01 & sig. & .41 \\
\hline \multirow{2}{*}{$\begin{array}{l}\text { Watching children's } \\
\text { entertainment and edu- } \\
\text { cational programmes }\end{array}$} & $r$ & & & & & & & 1 & $.49^{* *}$ & $r_{s}$ & $.12^{*}$ \\
\hline & sig. & & & & & & & & .000 & sig. & .02 \\
\hline \multirow{2}{*}{$\begin{array}{l}\text { Using the contents of te- } \\
\text { levision and internet for } \\
\text { educational purposes }\end{array}$} & $r$ & & & & & & & & 1 & $r_{s}$ & $.14^{* *}$ \\
\hline & sig. & & & & & & & & & sig. & .01 \\
\hline \multirow{2}{*}{$\begin{array}{l}\text { The number of books } \\
\text { in the room }\end{array}$} & $\begin{array}{c}r \\
\text { sia }\end{array}$ & & & & & & & & & $\mathrm{r}_{\mathrm{s}}$ & 1 \\
\hline & sig. & & & & & & & & & sig. & \\
\hline
\end{tabular}

**. Correlation is significant at the 0.01 level (2-tailed). ${ }^{\star}$. Correlation is significant at the 0.05 level (2-tailed). 
Significant positive correlations exist between general practices related to the use of electronic resources with different contents (cartoons on DVD, cartoons on cable TV, watching educational programmes appropriate to age, etc.) over a weekly span (Table 3). However, two practices were of particular interest to us - children watching ageappropriate entertainment and educational programmes and teachers using the contents of television and the Internet in joint activities with children to better illustrate the topic of the activity. Our results point to the conclusion that these two types of activities positively correlate with most of the other activities related to use of electronic resources.

Finally, with respect to the number of books available in rooms and the amount of watching TV or the related contents, negative correlations were found between the number of books and the frequency of watching cartoons on DVD (Spearman's $\mathrm{r}=-.13, \mathrm{p}<0.05)$. However, positive correlations were found between the number of books in the room and the frequency of watching cartoons on cable TV (Spearman's $\mathrm{r}=.15, \mathrm{p}<0.001$ ), the frequency of watching children's entertainment and educational programmes (Spearman's $\mathrm{r}=.12, \mathrm{p}<0.05$ ) and the frequency of using the contents of television and internet for educational purposes (Spearman's $\mathrm{r}=.14, \mathrm{p}<0.05$ ).

\section{Discussion}

In this paper we have attempted to explore the extent to which different resources and media (books vs. TV) are used in the context of emergent literacy development of kindergarten children and how kindergarten teachers organize their daily activities related to emergent literacy.

When we observe mere reading-related practices in kindergartens, it is clear these practices are embedded in the main activity for that day. However, they are positioned as tools that are not extended to the entire concept of emergent literacy. This is underlined by several results from our survey. First, the observed inconsistencies in teachers' reports on the presence of separate libraries in their own facilities, as well as on the number of books available in them, imply that teachers are not prone to diversify reading experiences for children. Second, from the perspective of creating a print rich environment (e.g. the results on the effects of reading programmes, the recommendation of minimum five books of different genres per child, availability of books etc.), it is questionable whether any of our facilities fulfil recommendations in that respect. If we bear in mind that an average kindergarten group has 20 to 30 children, even with the highest reported number of books in some central municipalities in Belgrade, this yields 1-3 books per child. Although it can be argued that effective teachers can provide various opportunities for children even with limited resources, our emphasis here is on the activities initiated by children themselves. In print rich environments children find these opportunities more easily.

As we have dealt only with kindergartens in the Serbian capital, where one assumes "resources are more available", concerns may be raised for small and rural communities, especially if we take into account the finding of the discrepancy in the number of books in favour of the centrally located kindergartens. Moreover, the titles available in our kindergartens are predominantly traditional fairy tales and fables, with fewer children's poetry books (important for the development of rhyme, i.e. phonological awareness), fewer cartoon inspired titles (e.g. Peppa Pig or Angelina Ballerina, suitable for the connection between two media: books and TV) or any of the new titles where organization of text and pictures is aligned with the emergent literacy concept (Mitrović, 2010b). However, the results do indicate that the development of emergent literacy takes place even without 
intentional effort. More than two thirds of kindergarten teachers said that children in their group exhibited emergent reading and writing behaviours, which was correlated with the regularity of teachers' reading. Yet, we have no data on the number of children in the group that exhibit such behaviour. Moreover, no significant correlations were found between the number of books available in rooms and the frequency of reading to the child by kindergarten educators. However, they were found between the number of books available and the child asking to be read to, and the number of books available in rooms and children's pretend reading activities. Thus, it is our belief that present practices focusing on the above-mentioned aspects should be also explored through an observational study, especially since even in the Book of regulations storybook reading is mentioned only as an activity which has to take place in front of the whole group, rather than individually or in small groups. In this way we would be able to better understand the meanings prescribed for actual daily activities, at what time reading takes place and under which conditions, as well as whether specific groups of children are more prone to emergent related reading and writing behaviours.

In this paper emergent literacy was described as a combination of different socioculturally and contextually determined practices. When we talk about literacy, we do not solely imply a simple encoding of oral language into written code (and vice versa), but any set of social practices that are mediated by written texts presented in different media: paper or electronic. With respect to that, our results have shown that kindergarten teachers read less to children if TV set is present in the room. This very result is not negative per se. The point where we can see that kindergarten teachers control the use of media is the finding that cable TV is practically banned from kindergartens (only $10 \%$ of kindergartens have cable TV), indicating that teachers take care about the kind of titles they present to children. However, since other results also point to the conclusion that TV or Internet are used as educational tools to a small extent, it seems much depends on kindergarten teachers' professional development regarding the use of media tools as a support in the development of emergent literacy. Once again, mixed results in other domains related to the use of TV in everyday activities (e.g. no significant correlations between the existence of TV sets in play rooms and pretend reading activities or the child asking to be read to vs. the negative correlation between presence of TVs in play rooms and the frequency of weekly reading initiated by the kindergarten teacher) call for a closer inspection of what actually takes place in play rooms when electronic media are used.

At the same time, in spite of somewhat inconclusive results on electronic media use in every day kindergarten activities, small but significant positive correlations were found between the frequencies of weekly reading initiated by the kindergarten teacher, the child asking to be read to or pretend to read activities and the frequency of children watching age-appropriate entertainment and educational programmes, and teachers using contents of television and the Internet for educational purposes. These findings are clearly in line with the ideas raised by authors advocating more media-rich emergent literacy curricula.

\section{Conclusions}

To our knowledge, this study is one of the first attempts to map and describe the practices related to the development of emergent literacy in Serbian kindergartens. We are aware that inspecting emergent literacy practices in kindergartens at the basic level is only one side of the story and that to fully comprehend how our environment perceives literacy, especially at young age, an in-depth analysis of kindergarten teachers' beliefs and observational studies covering current reading strategies should 
be made. In addition, home literacy environment should be investigated as well, especially as it is presumed to have a significant effect on the development of emergent literacy skills in preschool children. Further insight into existing parental beliefs and practices on emergent literacy should enlighten the phenomenon even more. The third line of research would have to include observation of children's behaviour in relation to emergent literacy, as well as an assessment of the skills that Whitehurst and Lonigan (1998) proposed as essential dimensions of emergent literacy (e.g. phonological awareness, vocabulary, knowledge of print concepts, etc.) This would allow incorporating emergent literacy in Serbian preschool educational programmes and building up professional development programmes in line with international policies and practices, but at the same time culturally appropriate.

\section{Literature}

American Academy of Pediatrics Council on Communications and Media (2011). Media use by children younger than 2 years. Pediatric, 128, 1040-1045.

Anđelković, D. (2012). Razvoj komunikacije: neverbalna komunikacija, govor i pismenost. U A. Baucal (ur.): Standardi za razvoj i učenje dece ranih uzrasta u Srbiji (str. 49-67). Beograd: Filozofski fakutet Univerziteta u Beogradu i Institut za psihologiju.

Anderson, D.R., Huston, A.C., Schmitt, K.L., Linebarger, D.L., Wright, J.C. (2001). Early childhood television viewing and adolescent behavior. Monographs of the Society for Research in Child Development, 66(1), 1-147.

Baucal, A. (2006). Development of mathematical and language literacy among Roma students. Psihologija, 39(2), 207-227.

Baucal, A., Pavlović-Babić, D., Gvozden, U. \& Plut, D. (2006). Obrazovna postignuća učenika trećeg razreda, Nacionalno testiranje 2004. Beograd: Zavod za vrednovanje kvaliteta obrazovanja i vaspitanja.

Book of regulations of fundamentals for preschool programmes (2006). Official Gazette RS No. 14/2006. [Pravilnik o opštim osnovama predškolskog programa (2006). Službeni glasnik RSProsvetni glasnik, Br. 14/2006.]

Book of regulations on educational resources necessary for work of preschool institutions (1994). Official Gazette No. 46/1994. [Pravilnik o normativu sredstava za realizaciju vaspitno-obrazovnog programa u predškolskoj ustanovi (1994). Službeni glasnik RS-Prosvetni glasnik, Br. 46/1994.]

Cunningham, A. E., \& Stanovich, K. E. (1997). Early reading acquisition and its relation to reading experience and ability 10 years later. Developmental Psychology, 33(6), 934-945.

Dragićević, R. (2006). Kultura izražavanja u nastavi srpskog jezika. Inovacije u nastavi, 19(1), 29-35.

Dragićević, R. (2012). Leksikologija i gramatika u školi. Beograd: Učiteljski fakultet.

Duncan, G. J., Dowsett, C. J., Claessens, A., Magnuson, K., Huston, A. C., Klebanov, P., Pagani, L.S., Feinstein, L., Engel, M., Brooks-Gunn, J., Sexton, H., Duckworth, K., \& Japel, C. (2007). School readiness and later achievement. Developmental Psychology, 43, 1428-1446.

Early Learning for Every Child Today (ELECT): A framework for Ontario early childhood settings (2007). Ontario Ministry of Children and Youth Services.

Gee, J.P. (1999). Reading and the new literacy studies: Reframing the National Academy of Sciences report on reading. Journal of Literacy Research, 31, 355-374.

Gersten, R., Compton, D., Connor, C.M., Dimino, J., Santoro, L., Linan-Thompson, S., and Tilly, W.D. (2008). Assisting students struggling with reading: Response to Intervention and multi-tier intervention for reading in the primary grades. A practice guide. (NCEE 20094045). Washington, DC: National Center for Education Evaluation and Regional Assistance, Institute of Education Sciences, U.S. Department of Education. Retrieved on March 14th, 2013 from the World Wide Web http://ies.ed.gov/ncee/wwc/publications/practiceguides/. 
Hart, B., \& Risley, T. R. (2003). The early catastrophe. The 30 million word gap. American Educator, 27(1), 4-9.

International Reading Association and the National Association for Education of Young Children [IRA/NAEYC] (1998). Learning to read and write: Developmentally appropriate practices for young children: Joint position Statement. Washington, DC: National Association for the Education of Young Children; and Newark, DE: International Reading Association.

Ispa, J.M. (2002). Russian child care goals and values: from Perestroika to 2001. Early Childhood Research Quarterly, 17, 393-413.

Joshi, M.R. (2010). Role of Orthography in Literacy Acquisition and Literacy Problems Among Monolinguals and Bilinguals, in D. Aram and O. Korat (Eds.), Literacy Development and Enhancement Across Orthographies and Cultures, Literacy Studies 101, (pp. 167-176), New York: Springer Science Business Media.

Krnjaić, Z., Stepanović I. \&, Pavlović-Babić D. (2011). Reading habits of secondary school students in Serbia. Zbornik Instituta za pedagoška istraživanja, 43(2), 266-282.

Lee J., Grigg W., Donahue, P. (2007). The Nation's Report Card: Reading 2007 (NCES 2007496). Washington, DC: National Center for Education Statistics, Institute of Education Sciences, US Department of Education.

Linebarger, D.L. \& Walker, D. (2005). Infants' and toddlers' television viewing and language outcomes. American Behavioural Scientist, 48(5), 624-645.

Mason, J. M., \& Shobha S. (1993). Emerging Literacy in the Early Childhood Years: Applying a Vygotskian Model of Learning and Development. In B. Spodek (Ed.), Handbook of Research on the Education of Young Children, 137-50. New York: MacMillan.

Mitrović, M. (2010a). Pismenost i obrazovanje: perspektive novih studija pismenosti. Beograd: Filozofski fakutet Univerziteta u Beogradu.

Mitrović, M. (2010b). Koncepcije pismenosti u bukvarima i početnicama. Pedagogija, 65(2), 183-193.

Mullis, I.V.S, Martin, M.O, Foy, P., \& Drucker, K.T. (2012): PIRLS 2011 International Results in Reading. Boston, USA: TIMSS \& PIRLS International Study Center, Lynch School of Education.

Neuman, S.B. \& Celano, D. (2001). Books Aloud: A campaign to "Put books in children's hands". Reading Teacher, 54, 550-557

Neuman, S.B. (1999). Books make a difference: A study of access to literacy. Reading Research Quarterly, 34, 286-301

Organization for Economic Co-operation and Development (OECD) (2006). Starting Strong II. Paris: OECD Secretariat.

Pavlović-Babić D. \& Baucal A. (2010). Reading literacy as a measure of the quality of education: Estimates based on PISA 2009 data. Psihološka istraživanja, 13(2), 241-260.

Pavlović-Babić D. \& Baucal, A. (2009). Razumevanje pročitanog: PISA 2003 i PISA 2006. Beograd: Ministarstvo prosvete Republike Srbije, Zavod za vrednovanje kvaliteta obrazovanja i vaspitanja, Institut za psihologiju Filozofskog fakulteta Univerziteta u Beogradu.

Pavlović-Babić, D. (1998). Reading in our teaching practice. Nastava i vaspitanje, 47 (5), 763-782.

Penuel, W. R., Pasnik, S., Bates, L., Townsend, E., Gallagher, L. P., Llorente, C., \& Hupert, N. (2009). Preschool teachers can use a media rich curriculum to prepare low income children for school success: Results of a randomized controlled trial. New York and Menlo Park, CA: Education Development Center, Inc., and SRI International.

Šefer, J., Lazarević, E. \& Stevanović, J. (2008). Jezik udžbenika: podsticaj ili prepreka, Zbornik Instituta za pedagoška istraživanja, 40(2), 347-368.

Sénéchal, M., LeFevre, J., Smith-Chant, B. L., \& Colton, K. (2001). On refining theoretical models of emergent literacy: The role of empirical evidence. Journal of School Psychology, 39, 439-460.

Seymour, P. H. K., Aro, M., \& Erskine, J. M. (2003). Foundation literacy acquisition in European orthographies. British Journal of Psychology, 94, 143-174. 
Skiver, J.A. (2011). Early literacy: towards a unified approach for childcare and school. Journal of Early Childhood Literacy, 12 (3), 311-330.

Snow, C. (2004).What counts as literacy in early childhood? In K. McCartney and D. Phillips (Eds.), Handbook of Early Child Development (pp. 274-295). Oxford: Blackwell.

Street, B. (2003). What's "new" in New Literacy Studies? Critical approaches to literacy in theory and practice. Current Issues in Comparative Education, Vol. 5(2), 77-91.

Strickland, D.S. \& Riley-Ayers S. (2006). Early Literacy: Policy and Practice in the Preschool Years. National Institute for Early Education Research [NIEER] Policy Brief (Issue 10, April 2006). Retrieved March $14^{\text {th }}, 2013$ from the World Wide Web http://nieer.org/publications/ policy-matters-policy-briefs/policy-brief-early-literacy-policy-and-practice-preschool.

Sulzby, E., \& Teale, W. H. (1996). Emergent literacy. In R. Barr, M. L. Kamil, P. Mosenthal, \& P. D. Pearson (Eds.), Handbook of reading research (Vol. 2, pp. 727-757). New York: Longman.

Tafa, E. (2008). Kindergarten reading and writing curricula in the European Union. Literacy, $42(3), 162-170$.

Teale, W. H., \& Sulzby, E. (Eds.) (1986). Emergent literacy: Writing and reading. Norwood, NJ: Ablex.

The Law on Preschool Education (2010). Official Gazette RS, Num. 18/2010 [Zakon o predškolskom vaspitanju i obrazovanju (2010). Službeni glasnik RS-Prosvetni glasnik, Br. 18/2010.]

U.S. Department of Education, Office of Elementary and Secondary Education (2002). No Child Left Behind:A Desktop Reference.Washington, D.C.

Vandewater, E.A., Bickham, D.S, \& Lee, J.H. (2006). Time well spent? Relating television use to children's free-time activities. Pediatrics, 117(2), 181-191.

Whitehurst, G. J., \& Lonigan, C. J. (1998). Child development and emergent literacy. Child Development, 69, $848-872$.

\section{Razvoj rane pismenosti u srpskim vrtićima: osnovni resursi i $s$ njima povezana praksa}

Nada Ševa,

Institut za pedagoška istraživanja, Beograd

Jelena Radišić,

Institut za pedagoška istraživanja, Beograd

Ovo istraživanje bavi se osnovnim resursima koji su na raspolaganju vrtićima i vaspitačima, a pominju se u literaturi kao podrška razvoju rane pismenosti kod dece uzrasta od 3 do 5 godina. Uzorak je obuhvatio 374 vaspitača iz deset različitih opština na teritoriji grada Beograda koji su popunili upitnik o učestalosti čitanja priča, broju i vrsti knjiga koje su deci na raspolaganju i upotrebi elektronskih medija (na primer, televizijskih programa, crtanih filmova) u svakodnevnom radu s decom. Rezultati istraživanja pokazuju da sadašnji obrazovni programi u Srbiji eksplicitno ne podržavaju razvoj rane pismenosti kod dece uzrasta od 3 do 5 godina. Iako čitanje koje inicira vaspitač predstavlja sastavni deo svakodnevnih aktivnosti u vrtiću, naši vrtići jedva da ispunjavaju neophodne uslove za obezbeđivanje okruženja bogatog štampanim materijalima (jedna do tri knjige u proseku, u poređenju sa minimum pet). Televizori postoje u $85 \%$ vrtića, dok su u $45 \%$ direktno pristupačni deci u njihovim sobama. Iako deca uglavnom gledaju televiziju jedan do tri puta nedeljno, ona se u najvećem broju slučajeva koristi za zabavu, dok samo $34 \%$ vaspitača televizor koristi kao obrazovno sredstvo u interakciji s decom. U zaključku se diskutuju mogućnosti za buduća istraživanja o praksi i stavovima povezanim sa ranom pismenošću, kako u vrtiću, tako i kod kuće.

Ključne reči: rana pismenost, praksa vaspitača, resursi vrtića 